\title{
Pengaruh Pelatihan Dan Motivasi Terhadap Kinerja Karyawan Pada Bank BJB di Cabang Balaraja Banten
}

\author{
${ }^{1}$ Rahmi Hermawati, ${ }^{2}$ Abdurrahman Firdaus, ${ }^{3} N$. Lilis Suryani, \\ ${ }^{4}$ Achmad Rozi, ${ }^{5}$ Heri Erlangga \\ ${ }^{1.2 .3}$ Universitas Pamulang, Tangerang Selatan, Banten, Indonesia \\ ${ }^{4}$ Universitas Primagraha, Serang, Banten, Indonesia \\ ${ }^{5}$ Universitas Pasundan, Bandung, Jawa Barat, Indonesia \\ Email: ${ }^{1}$ dosen00807@unpam.ac.id
}

(Diterima: April 2021; Direvisi: April 2021; Dipublikasikan: Mei 2021)

\begin{abstract}
ABSTRAK
Tujuan penelitian ini adalah untuk mengetahui pengaruh pelatihan dan motivasi terhadap kinerja karyawan pada Bank BJB Di Cabang Balaraja Banten baik secara parsial maupun secara simultan. Metode yang digunakan adalah metode yang digunakan dalam penelitian ini adalah asosiatif kausal dengan pendekatan kuantitatif. Teknik sampling yang digunakan adalah sampel jenuh menggunakan dengan 98 responden. Analisis data menggunakan uji validitas, uji reliabilitas, uji asumsi klasik, analisis regresi, analisis koefisien korelasi, analisis koefisien determinasi dan uji hipotesis. Hasil penelitian ini adalah bahwa pelatihan berpengaruh signifikan terhadap kinerja karyawan dengan persamaan regresi $\mathrm{Y}=$ $17,500+0.563 \mathrm{X} 1$, koefisien korelasi 0,659 artinya kedua variabel memiliki hubungan yang kuat dengan koefisien determinasi $43,4 \%$ dan Uji hipotesis diperoleh $\mathrm{t}$ hitung $>\mathrm{t}$ tabel atau $(8,587>1.985)$ Motivasi berpengaruh signifikan terhadap kinerja karyawan dengan persamaan regresi $\mathrm{Y}=15,802+0,607 \mathrm{X} 2$. Koefisien korelasinya sebesar 0,607 artinya keduanya memiliki hubungan yang kuat dengan koefisien determinasi sebesar 36,8\% dan uji hipotesis yang diperoleh $\mathrm{t}$ hitung $>\mathrm{t}$ tabel atau $(7,482>1,985)$. Pelatihan dan motivasi secara simultan berpengaruh signifikan terhadap kinerja karyawan dengan persamaan regresi $\mathrm{Y}=$ $11,164+0,394 \mathrm{X} 1+0,366 \mathrm{X} 2$. Nilai koefisien korelasinya yang diperoleh sebesar 0,713 artinya variabel independen dengan variabel dependen memiliki hubungan yang kuat dengan koefisien determinasi sebesar 50,8\% sedangkan sisanya 49,2\% dipengaruhi oleh faktor lain. Pengujian hipotesis diperoleh nilai $\mathrm{F}>\mathrm{F}$ tabel atau $(49,032>2,700)$ dengan demikian $\mathrm{H}_{0}$ ditolak dan $\mathrm{H}_{3}$ diterima. Artinya terdapat pengaruh simultan yang signifikan antara pelatihan dan motivasi terhadap kinerja karyawan pada Bank BJB Cabang Balaraja Banten.
\end{abstract}

\section{Kata Kunci: Pelatihan, Motivasi, Kinerja Karyawan.}




\section{PENDAHULUAN}

Perubahan demi perubahan yang sangat cepat dalam dunia kerja membutuhkan kesiapan perusahaan untuk terus dilatih beradaptasi setiap saat, sumber daya manusia mengambil peranan penting untuk dapat membantu perusahaan untuk mencapai tujuan tersebut. Dari dunia perbankan di Indonesia memasuki masa persaingan yang sangat kompetitif dengan daya saing tinggi. Hal ini disebabkan dengan banyaknya bank baik lokal ataupun internasional dan mulai berdirinya perusahaan yang berbasis fintech (Financial Technology).

Perbankan sendiri menjadi salah satu sektor strategis dalam meningkatkan pertumbuhan ekonomi bahkan hampir di setiap negara di dunia. Untuk saat ini perbankan bahkan dapat melewati krisis moneter dan bank baru mulai beradaptasi dengan memberikan pelayanan yang terbaik untuk para nasabahnya dengan kemudahan dalam mengakses produk produk perbankan seperti pembukaan rekening dan buku tabungan, kartu kredit, kredit pemilikan rakyat (KPR), dan produk jasa lainnya. Dunia perbankan dalam tahun ke tahun mengalami banyak sekali perubahan contoh seperti saat ini yang sangat mudah dalam pembuatan buku tabungan hanya dengan melalui telepon genggam atau smartphone tentu ini menjadi kemudahan bagi masyarakat yang mulai sadar akan pentingnya kebutuhan perbankan, baik karena adanya keamanan dalam bertransaksi dan berbisnis yang erat kaitannya dengan keuangan atau untuk meyimpan dananya guna kebutuhan saat ini dan yang akan datang. Dengan ketatnya persaingan tersebut yang mendorong kinerja pada setiap perusahaan lebih ditingkatkan khususnya perbankan.

Kesuksesan sebuah perusahaan atau organisasi sangat ditentukan dari kinerja setiap karyawannya dalam mengerjakan sesuatu diberikan kepada karyawan yang dituntut untuk mengerjakan seoptimal mungkin sehingga perusahaan atau organisasi tersebut dapat mencapai tujuan. Menurut Mangkunegara (2014:67) kinerja karyawan merupakan hasil kerja secara kualitas dan kuantitas yang dicapai seseorang karyawan dalam melaksanakan tugasnya sesuai dengan tanggung jawab yang diberikan kepadanya. Kinerja karyawan pada Bank BJB Cabang Balaraja Banten masih terlihat kurang efektif dikarenakan target yang diberikan tidak tercapai. Faktor tidak tercapainya target tersebut disebabkan kurangnya pelatihan dan motivasi karyawan pada Bank BJB Cabang Balaraja Banten.

Pelatihan adalah suatu proses yang meliputi serangkaian tindakan yang dilaksanakan dalam bentuk pemberian bantuan kepada tenaga kerja atau karyawan oleh tenaga profesional yang bertujuan untuk meningkatkan kemampuan dan kompetensi kerja dalam bidang pekerjaan yang berguna untuk efektivitas dan produktifitas dalam suatu perusahaan. Dalam menghadapi tantangan dan mendukung karyawan harus melakukan pengembangan diri. Menurut Gary Dessler (2015:284) pelatihan merupakan proses mengajarkan pegawai baru atau yang ada sekarang, keterampilan dasar mereka butuhkan untuk menjalankan pekerjaan mereka. Pelatihan 
merupakan salah satu usaha dalam meningkatkan sumber daya manusia dalam dunia kerja. Dengan adanya kegiatan pelatihan, karyawan memiliki kesempatan untuk menyerap pengetahuan baru atau nilai-nilai baru, sehingga dengan pengetahuan tersebut para karyawan dapat meningkatkan kemampuan dalam melaksanakan tugas yang dibebankan kepadanya. Tuntutan bahwa karyawan harus bekerja dengan tingkat kinerja yang tinggi, karyawan membutuhkan motivasi untuk merangsang karyawan agar lebih produktif dan berkembang demi kemajuan perusahaan.

Motivasi menurut Hasibuan (2016:97) mengungkapkan bahwa pemberian daya penggerak yang menciptakan kegairahan kerja seseorang, agar mereka mau bekerja sama, bekerja efektif dan terintegrasi dengan untuk mencapai kepuasan.

Berjalannya sebuah perusahaan tak hanya bergantung pada keuntungan yang berasal dari pendapatan perusahaan saja melainkan juga pentingnya menjaga sumber daya manusia yang ada yaitu karyawan. Salah satu bentuk menjaga dan mengembangkan sumber daya manusia yang ada maka dibutuhkanlah sebuah pelatihan.

Adanya peningkatan dan penurunan karyawan yang mengikuti pelatihan dalam kurun 3 tahun terakhir. Pada tahun 2017 dari total 105 karyawan hanya sekitar 67 orang atau $63,81 \%$ yang mengikuti pelatihan dan pada tahun selanjutnya yaitu 2018 yang menjadi 71 orang atau $60,68 \%$ dari total 117 karyawan secara jumlah karyawan yang mengikuti lebih banyak akan tetapi persentase mengalami penurunan dari tahun sebelumnya.

Pada tahun 2019 mengalami penurunan persentase dengan peserta pelatihan sebesar $56,12 \%$. Dengan data tersebut di atas menunjukkan adanya penurunan pada setiap tahunnya dan hasil ini masih belum mencapai target yang ditentukan, realisasi tersebut masih jauh dari target yang sudah ditentukan. Dengan hal tersebut menunjukkan kurang optimalnya pelatihan yang diberikan karena masih terdapat karyawan yang belum mengikuti pelatihan terhitung cukup banyak. Sehingga hal yang diharapkan adalah tahun tahun berikutnya jumlah peserta akan semakin banyak guna tercapainya target yang bertujuan untuk meningkatkan kinerja karyawan pada Bank BJB Cabang Balaraja Banten

\section{TINJAUAN PUSTAKA}

\section{Kinerja}

Kinerja pada dasarnya memiliki banyak arti berdasarkan sudut pandang para ahli menurut Mangkunegara (2015:67) kinerja (prestasi kerja) adalah hasil kerja secara kualitas dan kuantitas yang dicapai oleh seseorang pegawai dalam melaksanakan tugasnya sesuai dengan tanggung jawab yang diberikan kepadanya. Kinerja karyawan merupakan hasil keluaran yang dilakukan individu karyawan dalam satu periode tertentu.Definisi kinerja karyawan menurut Wilson Bangun (2012:231) menuliskan kinerja (performance) merupakan hasil pekerjaan yang dicapai seseorang berdasarkan persyaratanpersyaratan pekerjaan (job requirement). Suatu pekerjaan 
akan mempunyai persyaratan tertentu untuk dapat dilakukan dalam mencapai tujuan yang disebut juga sebagai standar pekerjaan (job standard).

\section{Pelatihan}

Menurut Rivai (2011:212) Pelatihan adalah proses secara sistematis mengubah tingkah laku pegawai untuk mencapai tujuan organisasi. Pelatihan berkaitan dengan keahlian dan kemampuan pegawai untuk melaksanakan pekerjaan saat ini. Pelatihan memiliki orientasi saat ini dan membantu pegawai untuk mencapai keahlian dan kemampuan tertentu agar berhasil dalam melaksanakan pekerjaannya. Pelatihan menurut Sinambela (2016:169) pelatihan merupakan salah satu faktor penting dalam pengembangan sumber daya manusia, pendidikan dan pelatihan tidak hanya menambah pengetahuan, tetapi juga meningkatkan keterampilan bekerja sehingga meningkatkan produktivitas dalam bekerja. Menurut Garry Dessler (2011:5) pelatihan adalah proses mengejar keterampilan yang dibutuhkan karyawan baru untuk melakukan pekerjaannya.

Berdasarkan beberapa definisi di atas maka disimpulkan bahwa pelatihan merupakan suatu kegiatan yang dilakukan oleh suatu organisasi atau perusahaan untuk meningkatkan kemampuan karyawannya berupa pengetahuan atau sikap yang lebih baik untuk menunjang pekerjaan sehingga dapat berhasil dalam melaksanakan pekerjaannya.

\section{Motivasi}

Motivasi merupakan dorongan, daya penggerak atau kekuatan yang menyebabkan suatu tindakan atau perbuatan. Motivasi dalam bahasa inggris adalah motivation yang berarti pemberian motif, penimbulan motif, atau hal yang menimbulkan dorongan atau keadaan yang menimbulkan dorongan. Secara harfiah motivasi berarti pemberian motif. Motif dasar dari seseorang tersebut adalah adanya kebutuhan seseorang tersebut akan kebanggaan dan kehormatan serta mungkin limpahan materi.

Menurut Hasibuan S.P (2017:141), Motivasi berasal dari kata latin movere yang berarti dorongan atau menggerakkan. Motivasi dalam manajemen hanya ditujukan pada sumber daya manusia umumnya dan bawahan khususnya. Motivasi mempersoalkan bagaimana caranya mengarahkan daya dan potensi bawahan agar mau bekerja sama secara produktif berhasil mencapai dan mewujudkan tujuan yang ditentukan. Menurut Hamalik (2017:173) motivasi merupakan energi dalam diri atau pribadi seseorang yang ditandai dengan timbulnya perasaan dan reaksi untuk mencapai tujuan. Menurut Azwar (2017:73) motivasi merupakan rangsangan dorongan ataupun pembangkit tenaga yang dimiliki seseorang atau sekelompok masyarakat yang mau berbuat dan bekerjasama secara optimal dalam melaksanakan sesuatu yang telah direncanakan untuk mencapai tujuan yang telah ditetapkan. 
Dari uraian di atas dapat disimpulkan bahwa motivasi merupakan sebuah dorongan atau dukungan manajemen kepada karyawan agar mau bekerja secara giat agar tujuan yang diinginkan berhasil secara optimal.

\section{METODE PENELITIAN}

Populasi dalam penelitian ini adalah seluruh karyawan Bank BJB Cabang Balaraja Banten 98 orang, sampel digunakan metode Sampling Jenuh (sensus). Menurut Sugiyono (2014:118) "teknik sampling jenuh adalah teknik penentuan sampel bila adalah teknik penentuan sampel bila semua anggota populasi digunakan sebagai sampel. Sampel dalam penelitian ini sebanyak 98 karyawan atau responden.

Pengumpulan data merupakan upaya untuk mendapatkan informasi yang akan digunakan dalam pengukuran variabel. Menurut Sugiyono (2017:308) menyampaikan "metode pengumpulan data adalah cara ilmiah untuk mendapatkan data yang valid dengan tujuan dapat dibuktikan, dikembangkan suatu pengetahuan sehingga dapat digunakan memecahkan dan mengantisipasi masalah". Dalam teknik pengumpulan data, peneliti memperoleh data dengan data primer yaitu data yang diperoleh secara langsung oleh peneliti melalui studi lapangan untuk mendapatkan dan mengumpulkan informasi dari sumbernya sekaligus menjawab masalah dan tujuan penelitian. Dalam penelitian ini data primernya berupa observasi dan penyebaran kuesioner serta data sekunder yaitu data yang diperoleh secara tidak langsung dan didapatkan dari sumber yang sudah ada yaitu data dari dalam perusahaan berupa file dan dari objek penelitian berupa dokumen atau laporanlaporan, gambaran umum lokasi penelitian dan data lainnya yang relevan dengan penelitian ini, dapat diperoleh dari buku, majalah, skripsi maupun literatur lainnya (Library Research). Dalam penelitian ini data sekundernya berupa studi kepustakaan dan dokumentasi berupa bukti, catatan atau laporan historis yang telah tersusun dalam arsip atau file dokumenter diperusahaan.

\section{HASIL DAN DISKUSI}

Setelah seluruh data yang diperoleh dalam penelitian di uraikan, maka pada tahap selanjutnya akan dilakukan pembahasan data yang telah diuraikan tadi, interpretasi data secara keseluruhan untuk masing masing variabel dapat dilakukan setelah terlebih dahulu diklarifikasikan berdasarkan nilainilai yang diperoleh dari responden.

Setelah kuesioner disebarkan, kemu-dian dilakukan pengujian instrumen data sebagai alat pembuktian meliputi uji validitas dan uji reliabilitas.

Tabel 1. Uji Validitas

\begin{tabular}{|c|c|c|c|c|}
\hline \multicolumn{5}{|c|}{ VARIABEL } \\
\cline { 1 - 3 } Pelatihan & Motivasi & Kinerja & \multirow{2}{*}{ r tabel } & Keputusan \\
\cline { 1 - 3 }$r$ hitung & r hitung & r hitung & & \\
\hline 0.427 & 0.514 & 0.518 & 0.199 & Valid \\
\hline 0.340 & 0.383 & 0.334 & 0.199 & Valid \\
\hline 0.329 & 0.488 & 0.383 & 0.199 & Valid \\
\hline 0.563 & 0.439 & 0.445 & 0.199 & Valid \\
\hline 0.737 & 0.401 & 0.607 & 0.199 & Valid \\
\hline 0.473 & 0.372 & 0.454 & 0.199 & Valid \\
\hline 0.762 & 0.574 & 0.649 & 0.199 & Valid \\
\hline 0.766 & 0.535 & 0.574 & 0.199 & Valid \\
\hline 0.681 & 0.481 & 0.598 & 0.199 & Valid \\
\hline 0.501 & 0.586 & 0.352 & 0.199 & Valid \\
\hline
\end{tabular}

Sumber: Data Olah 2020

Berdasarkan data tabel di atas, variabel kinerja karyawan (Y) diperoleh nilai $\mathrm{r}$ hitung $>\mathrm{r}$ tabel 
(0.199), dengan demikian maka semua item kuesioner dinyatakan valid. Untuk itu kuesioner yang digunakan layak untuk diolah sebagai data penelitian.

Tabel 2. Uji Reliabilitas

Reliability Statistics

\begin{tabular}{c|c} 
Cronbach's Alpha & N of Items \\
\hline .746 & 10 \\
\hline \multicolumn{2}{c}{ Reliability Statistics } \\
Cronbach's Alpha & N of Items \\
\hline .620 & 10 \\
\hline \multicolumn{2}{|c}{ Reliability Statistics } \\
Cronbach's Alpha & N of Items \\
\hline .644 & 10 \\
\hline
\end{tabular}

Sumber: Data Olah 2020

Berdasarkan hasil pengujian pada tabel di atas, menunjukkan bahwa variabel pelatihan $\left(\mathrm{X}_{1}\right)$ diperolwh nilai Chronbath Alpha sebesar 0,746, motivasi $\left(\mathrm{X}_{2}\right)$ sebesar 0,620 dan kinerja karyawan (Y) sebesar 0,644 dimana semua variabel dinyatakan reliabel, hal itu dibuktikan dengan masing-masing variabel memiliki nilai Chronbath Alpha lebih besar dari 0,600 .

Langkah selanjutnya adalah melakukan uji prasayarat atau uji asumsi klasik. Uji asumsi klasik digunakan untuk mengetahui ketepatan data, atau keberartian hubungan antara variabel independen dengan variabel dependen sehingga hasil analisis dapat diinterpretasikan dengan lebih akurat, efisien, dan terhindar dari kelemahan-kelemahan yang terjadi karena masih adanya gejala-gejala asumsi klasik atau layak atau tidak data yang dipakai dilanjutkan sebagai data penelitian. Dari hasil penelitian maka dapat diketahui sebagai berikut:

1. Uji Normalitas

Uji Normalitas dalam penelitian ini menggunakan Kolmogorov-Smirnov Test dengan syarat significancy $\alpha>0.050$. Adapun hasil uji normalitas dengan Kolmogorov-Smirnov sebagai berikut:

Tabel 3. Hasil Uji Normalitas

Tests of Normality

\begin{tabular}{lcc|c|c|c|c|} 
& \multicolumn{3}{c}{ Kolmogorov-Smirnova } & \multicolumn{3}{c}{ Shapiro-Wilk } \\
& Statistic & Df & \multicolumn{1}{c}{ Sig. } & Statistic & Df & Sig. \\
\hline Kinerja Karyawan $(\mathrm{Y})$ & .087 & 98 & .066 & .977 & 98 & .084 \\
\hline
\end{tabular}

a. Lilliefors Significance Correction

Sumber: Data Olah 2020

Berdasarkan hasil pengujian pada tabel di atas, diperoleh nilai signifikansi $0,066>0,050)$. Dengan demikian maka asumsi distribusi persamaan pada uji ini adalah normal.
2. Uji Multikolinieritas

Uji mutlikolinearitas dilakukan untuk meyakini bahwa antar variabel bebas tidak memiliki multikolinearitas atau tidak memiliki hubungan korelasi antara variabel independen. Model regresi yang baik seharusnya tidak terjadi korelasi di antara variabel independen. 
Tabel 4. Hasil Uji Multikolinieritas

\begin{tabular}{|c|c|c|c|c|c|c|c|c|}
\hline \multicolumn{9}{|c|}{ Coefficients $^{a}$} \\
\hline \multirow{2}{*}{\multicolumn{2}{|c|}{ Model }} & \multicolumn{2}{|c|}{$\begin{array}{l}\text { Unstandardized } \\
\text { Coefficients }\end{array}$} & \multirow{2}{*}{$\begin{array}{c}\text { Standardized } \\
\text { Coefficients } \\
\text { Beta }\end{array}$} & \multirow[b]{2}{*}{$t$} & \multirow[b]{2}{*}{ Sig. } & \multirow{2}{*}{$\begin{array}{l}\text { Collinearity } \\
\text { Tolerance }\end{array}$} & \multirow{2}{*}{$\begin{array}{c}\text { Statistics } \\
\text { VIF }\end{array}$} \\
\hline & & B & Std. Error & & & & & \\
\hline 1 & (Constant) & 11.167 & 2.880 & & 3.878 & .000 & & \\
\hline & Pelatihan (X1) & .394 & .076 & .462 & 5.192 & .000 & .654 & 1.528 \\
\hline & Motivasi (X2) & .336 & .089 & .335 & 3.768 & .000 & .654 & 1.528 \\
\hline
\end{tabular}

Sumber: Data Olah 2020

Berdasarkan hasil pengujian multikolinieritas pada tabel di atas diperoleh nilai tolerance variabel pelatihan sebesar 0,654 dan motivasi sebesar 0,654, dimana kedua nilai tersebut kurang dari 1 , dan nilai Variance Inflation Factor (VIF) variabel pelatihan sebesar 1,528 serta motivasi sebesar 1,528 dimana nilai tersebut kurang dari 10. Dengan demikian model regresi ini tidak ada gangguan multikolinearitas.

Uji autokorelasi di maksudkan untuk mengetahui ada atau tidaknya penyimpangan korelasi antar anggota sampel. Untuk mengetahui adanya autokorelasi dilakukan pengujian Durbin-Watson (DW) dengan membandingkan antara nilai Durbin-Watson dengan kriteria atau pedoman dalam interpretasi. Adapun kriteria pedoman Uji Darbin-Watson (DW Test) yang menjadi acuannya adalah sebagai 3. Uji Autokorelasi berikut ini:

Tabel 5. Hasil Uji Autokorelasi

\begin{tabular}{|c|c|c|c|c|c|}
\hline \multicolumn{6}{|c|}{ Model Summary ${ }^{b}$} \\
\hline Model & $\mathrm{R}$ & R Square & $\begin{array}{l}\text { Adjusted R } \\
\text { Square }\end{array}$ & $\begin{array}{l}\text { Std. Error of the } \\
\text { Estimate }\end{array}$ & Durbin-Watson \\
\hline$\overline{1}$ & $.713^{\mathrm{a}}$ & .508 & .498 & 2.449 & 2.053 \\
\hline
\end{tabular}

Sumber: Data Olah 2020

Berdasarkan hasil pengujian pada tabel di atas, model regresi ini tidak ada autokorelasi, hal ini dibuktikan dengan nilai DurbinWatson sebesar 2,053 yang berada diantara interval $1.550-2.460$.

4. Uji Heterokedastisitas

Pengujian heteroskedastisitas dimak-sudkan untuk menguji apakah dalam sebuah model

Tabel 6 Hasil Uji Heteroskesdastisitas

Coefficients ${ }^{a}$

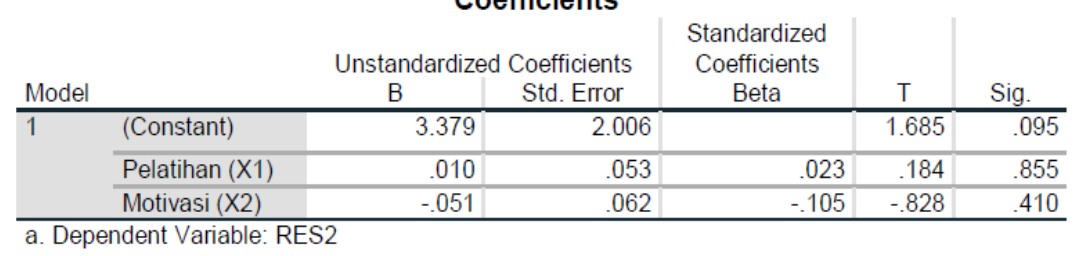

Sumber: Data Olah 2020 regresi terjadi ketidaksamaan varians residual. Salah satu cara untuk mendeteksi ada tidaknya heteroskedastisitas adalah dengan uji Glejser dimana hasil uji ini dapat dilihat apakah dalam model regresi terjadi ketidaksamaan varian dari suatu residual pengamatan ke pengamatan lain. 
Berdasarkan hasil pengujian pada tabel di atas, glejser test model pada variabel pelatihan (X1) diperoleh nilai probability signifikansi (Sig.) sebesar 0,855 dan motivasi (X2) diperoleh nilai probability signifikansi (Sig.) sebesar 0,410 dimana keduanya nilai signifikansi (Sig.) > 0,05. Dengan demikian regression model pada data ini tidak ada gangguan heteroskesdastisitas, sehingga model regresi ini layak dipakai sebagai data penelitian

Berdasarkan klasifikasi yang telah ditentukan, maka keseluruhan data yang diperoleh dari responden untuk masing- masing variabel penelitian dapat dijabarkan sebagai berikut :

\section{Pengaruh Pelatihan $\left(\mathbf{X}_{1}\right)$} Terhadap Kinerja Karyawan (Y).

Berdasarkan hasil analisis, diperoleh nilai persamaan regresi $\mathrm{Y}=17,500+0,563 \mathrm{X}_{1}$, koefisien korelasi sebesar 0,659 artinya kedua variabel mempunyai tingkat hubungan yang kuat. Nilai determinasi atau kontribusi pengaruh sebesar 0,434 atau sebesar $43,4 \%$ sedangkan sisanya sebesar $56,6 \%$ dipengaruhi oleh faktor lain. Uji hipotesis diperoleh nilai $\mathrm{t}$ hitung $>\mathrm{t}$ tabel atau $(8,587$ $>1,985)$. Dengan demikian $\mathrm{H}_{0}$ ditolak dan $\mathrm{H}_{1}$ diterima artinya terdapat pengaruh yang signifikan antara pelatihan terhadap kinerja karyawan pada Bank BJB Cabang Balaraja Banten.

Jadi dalam kasus ini dapat disimpulkan bahwa pelatihan berpengaruh terhadap kinerja, sehingga hipotesis awal yang menyatakan bahwa ada pengaruh yang signifikan antara pelatihan terhadap kinerja dapat diterima. Hasil ini sejalan dengan teori yang dikemukakan oleh Gary Dessler (2015-284) pelatihan merupakan proses mengajarkan pegawai baru atau yang ada sekarang, keterampilan dasar mereka butuhkan untuk menjalankan pekerjaan mereka. Pada salah satu indikator pelatihan yaitu peserta pelatihan adalah karyawan yang diberikan pengetahuan, kompetensi, dan kemampuan yang berguna untuk menjalan tugas dan tanggung jawabnya selama bekerja. Ketika peserta pelatihan yang dipilih tidak sesuai dengan bidang dan posisinya, maka pengetahuan dan hasil yang diterima dari pelatihan tidak efektif sehingga dalam menjalankan pekerjaanya kurang maksimal. Dengan memilih peserta pelatihan yang sesuai dengan tugas dan tanggung jawabnya maka karyawan akan merasa memiliki pengetahuan dan kemampuan dalam menjalankan kegiatan bekerja yang berpengaruh terhadap kinerja.

2. Pengaruh Motivasi $\left(\mathbf{X}_{2}\right)$ Terhadap Kinerja Karyawan (Y)

Berdasarkan hasil pengujian, diperoleh nilai persamaan regresi $\mathrm{Y}=15,802+0,607 \mathrm{X}_{2}$, koefisien korelasi sebesar 0,607 artinya kedua variabel mempunyai tingkat hubungan yang kuat. Nilai determinasi atau kontribusi pengaruh sebesar 0,368 atau sebesar $36,8 \%$ sedangkan sisanya sebesar $63,2 \%$ dipengaruhi oleh faktor lain. Uji hipotesis diperoleh nilai $\mathrm{t}$ hitung $>\mathrm{t}$ tabel atau $(7,482$ 
$>$ 1,985). Dengan demikian $\mathrm{H}_{0}$ ditolak dan $\mathrm{H}_{2}$ diterima artinya terdapat pengaruh yang signifikan antara motivasi terhadap kinerja karyawan pada Bank BJB Cabang Balaraja Banten. Jadi dalam kasus ini dapat disimpulkan bahwa motivasi berpengaruh terhadap kinerja, sehingga hipotesis awal yang menyatakan bahwa ada pengaruh yang signifikan antara motivasi terhadap kinerja dapat diterima

Hasil ini sejalan dengan teori yang dikemukakan oleh Mc Clelland dalam Hasibuan (2016:95) bahwa motivasi kerja karyawan dipengaruhi oleh kebutuhan akan berprestasi, kebutuhan akan berafiliasi, kebutuhan akan kekuasaan. Pada salah satu indikator yaitu kebutuhan akan berprestasi adalah suatu keinginan untuk meraih hasil, mengatasi, dan mengalahkan suatu tantangan untuk kemajuan perusahaan. Ketika keinginan berprestasi karyawan menurun sesuai data yang diperoleh, maka keinginan untuk meraih hasil lebih untuk kemajuan perusahaan akan berjalan kurang efektif. Jika

keinginan karyawan akan berprestasi tinggi maka hasil dari tugas dan tanggung jawabnya dalam bekerja akan semakin baik yang secara signifikan berpengaruh terhadap kinerja perusahaan.

3. Pengaruh Pelatihan $\left(\mathrm{X}_{1}\right)$ dan Motivasi $\left(\mathbf{X}_{2}\right)$ Terhadap Kinerja Karyawan (Y)

Berdasarkan hasil penelitian, menunjukkan bahwa pelatihan $\left(\mathrm{X}_{1}\right)$ dan motivasi $\left(\mathrm{X}_{2}\right)$ berpengaruh positif terhadap kinerja karyawan dengan diperoleh persamaan regresi $\mathrm{Y}=$ $11,164+0,394 X_{1}+0,336 X_{2}$. Nilai koefisien korelasi atau tingkat pengaruh antara variabel bebas dengan variabel terikat diperoleh sebesar 0,713 artinya memiliki memiliki hubungan yang kuat. Nilai koefisien determinasi atau kontribusi pengaruh secara simutan sebesar $50,8 \%$ sedangkan sisanya sebesar $49,2 \%$ dipengaruhi oleh faktor lain. Uji hipotesis diperoleh nilai $F_{\text {hitung }}>F_{\text {tabel }}$ atau $(49,032>2,700)$. Dengan demikian $\mathrm{H}_{0}$ ditolak dan $\mathrm{H}_{3}$ diterima. Artinya terdapat pengaruh yang signifikan secara simultan antara pelatihan dan motivasi terhadap kinerja karyawan pada Bank BJB Cabang Balaraja Banten. Jadi dalam kasus ini dapat disimpulkan bahwa pelatihan dan motivasi berpengaruh terhadap kinerja, sehingga hipotesis awal yang menyatakan diduga ada pengaruh pelatihan dan motivasi terhadap kinerja karyawan secara simultan dapat diterima.

Hasil ini sejalan dengan toeri yang dikemukakan oleh Mangkunegara (2014:67) Kinerja karyawan merupakan hasil kerja secara kualitas dan kuantitas yang dicapai seseorang karyawan dalam melaksanakan tugasnya sesuai dengan tanggung jawab yang diberikan kepadanya. Pada salah satu indikator yang terdapat dalam teori tersebut yaitu kualitas kerja adalah seberapa baik seseorang karyawan mengerjakan apa yang seharusnya dikerjakan. Dengan peserta pelatihan yang tidak menerima pelatihan sesuai dengan 
tugas dan tanggung jawabnya serta keinginan untuk beprestasi yang dimiliki karyawan rendah maka akan berpengaruh terhadap kualitas kerja karyawan dengan hal tersebut maka kinerja karyawan akan menurun. Jika peserta pelatihan dipilih sesuai dengan tugas dan tanggung jawabnya serta mensimulasikan hasil pelatihannya langsung dalam pekerjaan dan keinginan untuk berprestasi yang bertujuan untuk kemajuan karyawan serta perusahaan mampu ditingkatkan maka kinerja karyawan akan tercapai sesuai dengan tujuan perusahaan dan organisasi yang telah ditentukan.

\section{KESIMPULAN DAN SARAN \\ A. Kesimpulan}

Berdasarkan uraian dan dari hasil analisis serta pembahasan mengenai pengaruh pelatihan dan motivasi terhadap kinerja karyawan, sebagai berikut:

1. Pelatihan berpengaruh signifikan terhadap kinerja karyawan dengan persamaan regresi $\mathrm{Y}=17,500+$ $0,563 \mathrm{X}_{1}$, nilai konstanta sebesar 17,500 dapat diartikan bahwa jika variabel pelatihan tidak ada, maka telah terdapat nilai kinerja karyawan sebesar 17,500 point. Nilai koefisien regresi pelatihan sebesar 0,563 diartikan apabila konstanta tetap dan tidak ada perubahan pada variabel motivasi, maka setiap perubahan 1 unit pada variabel pelatihan akan mengakibatkan terjadinya perubahan pada kinerja karyawan sebesar 0,563 point. Nilai korelasi sebesar 0,659 artinya kedua variabel memiliki tingkat hubungan yang kuat dengan koefisien determinasi sebesar $43,4 \%$. Uji hipotesis diperoleh $\mathrm{t}$ hitung > t tabel atau (8,587 > 1,985). Dengan demikian $\mathrm{H}_{0}$ ditolak dan $\mathrm{H}_{1}$ diterima artinya terdapat pengaruh signifikan antara pelatihan terhadap kinerja karyawan.

2. Motivasi berpengaruh signifikan terhadap kinerja karyawan dengan persamaan regresi $\mathrm{Y}=15,802+0,607 \mathrm{X}_{2}$ nilai konstanta sebesar 15,802 diartikan bahwa jika variabel motivasi tidak ada, maka telah terdapat nilai kinerja karyawan sebesar 15,802 point. Nilai koefisien regresi motivasi sebesar 0,607 diartikan apabila konstanta tetap dan tidak ada perubahan pada variabel pelatihan, maka setiap perubahan 1 unit pada variabel motivasi akan mengakibatkan terjadinya perubahan pada kinerja karyawan sebesar 0,607 pount. Nilai korelasi sebesar 0,607 artinya kedua memiliki tingkat hubungan yang kuat dengan koefisien determinasi sebesar $36,8 \%$. Uji hipotesis diperoleh $\mathrm{t}$ hitung $>\mathrm{t}$ tabel atau $(7,482>1,985)$. Dengan demikian $\mathrm{H}_{0}$ ditolak dan $\mathrm{H}_{2}$ diterima artinya terdapat pengaruh signifikan antara motivasi terhadap kinerja karyawan.

3. Pelatihan dan motivasi berpengaruh signifikan terhadap kinerja karyawan dengan persamaan regresi $\mathrm{Y}=$ $11,164+0,394 \mathrm{X}_{1}+0,336 \mathrm{X}_{2}$. Nilai konstanta sebesar 11,164 diartikan bahwa jika variabel pelatihan dan motivasi tidak 
dipertimbangkan maka, kinerja karyawan hanya akan bernilai sebesar 11,164 point. Nilai pelatihan 0.394 diartikan apabila konstanta tetap dan tidak ada perubahan pada variabel motivasi, maka setiap perubahan 1 unit pada variabel pelatihan akan mengakibatkan terjadinya perubahan pada kinerja karyawan sebesar 0,394 point. Nilai motivasi 0,336 diartikan apabila konstanta tetap dan tidak ada perubahan pada variabel pelatihan, maka setiap perubahan 1 unit pada variabel motivasi akan mengakibatkan terjadinya perubahan pada kinerja karyawan sebesar 0,336 point . Nilai korelasi sebesar 0,713 artinya variabel bebas dengan variabel terikat memiliki tingkat hubungan yang kuat dengan koefisien determinasi sebesar 50,8\% sedangkan sisanya sebesar 49,2\% dipengaruhi faktor lain. Uji hipotesis diperoleh nilai $F$ hitung $>F_{\text {tabel }}$ atau $(49,032>2,700)$. Dengan demikian $\mathrm{H}_{0}$ ditolak dan $\mathrm{H}_{3}$ diterima. Artinya terdapat pengaruh signifikan secara simultan antara pelatihan dan motivasi terhadap kinerja karyawan di Bank BJB Cabang Balaraja Banten.

\section{B. Saran}

1. Berdasarkan jawaban responden pada kuesioner dengan indikator pelatihan pernyataan yang paling lemah adalah nomor 2 yaitu keterampilan para instruktur dalam menyampaikan materi mudah dimengerti dengan rata rata score sebesar 3,39 dan jawaban responden kurang setuju sebesar 47\%. Hal tersebut di atas menunjukkan bahwa kurangnya para instruktur dalam memberikan pemahaman materi kepada karyawan. Perusahaan diharapkan lebih baik lagi dalam mencari dan menyiapkan instruktur yang mampu memberikan materi dengan baik serta mudah dimengerti untuk karyawan yang mengikuti pelatihan.

2. Berdasarkan jawaban responden pada kuesioner dengan indikator motivasi pernyataan yang paling lemah adalah nomor 2 yaitu penghargaan dalam pekerjaan dapat memotivasi karyawan dalam bekerja dengan rata rata score sebesar 3,37 dan jawaban responden kurang setuju sebesar $48 \%$. Hal ini menunjukkan bahwa kurangnya penghargaan yang diberikan oleh perusahaan kepada karyawan, dengan hal tersebut perusahaan diharapkan untuk lebih baik lagi dalam memberikan penghargaan dari yang sudah berjalan saat ini seperti kenaikan jabatan, gaji, serta reward tambahan lainnya yang berguna meningkatkan motivasi kerja para karyawan.

3. Berdasarkan jawaban responden pada kuesioner indikator kinerja karyawan pernyataan yang paling lemah adalah nomor 2 yaitu dengan pengetahuan yang karyawan miliki, penguasaan bidang 
tugas yang di kerjakan dengan hasil yang baik mencapai jawaban dengan rata rata score sebesar 3,39 dan jawaban responden kurang setuju sebesar 47\%. Hal ini menunjukkan bahwa kurangnya kompetensi yang disebabkan karena kurangnya pelatihan yang diberikan oleh perusahaan serta tingkat motivasi yang rendah terlihat dari keinginan karyawan untuk berprestasi yang berpengaruh untuk mencapai kinerja sesuai tujuan perusahaan. Berdasarkan hal tersebut perusahaan diharapkan dapat memberikan pelatihan kepada setiap karyawan agar memperoleh pengetahuan, kompetensi, serta skill yang dapat mendukung karyawan dalam menyelesaikan pekerjaan dan tanggung jawabnya serta memberikan motivasi dengan kebijakan-kebijakan yang bertujuan untuk mendorong karyawan dalam mencapai kinerja yang sesuai dengan tujuan perusahaan.

\section{DAFTAR PUSTAKA}

Algifari (2015). Analisis Regresi untuk Bisnis dan Ekonomi. Yogyakarta: BPFE.

Ardana, I Komang dkk. (2012) Manajemen Sumber Daya Manusia. Yogyakarta: Graha ilmu.

Bangun, W. (2012). Manajemen Sumber Daya Manusia. Jakarta: PT. Glora Aksara Pratama.

Bangun, Wilson. (2012). Manajemen Sumber Daya Manusia. Jakarta: Erlangga.
Bangun, Wilson. (2016). Manajemen Sumber Daya Manusia. Jakarta: Erlangga.

Dessler, Gary. (2010). Manajemen Sumber Daya Manusia Jilid 1. Jakarta: PT. Indeks.

Ghozali, Imam. (2017). Aplikasi Analisis Multivariate Dengan Program SPSS. Edisi Kelima. Semarang: Badan Penerbit Undip.

Hanafi, B. D., \& Yohana, C. (2017). Pengaruh Motivasi dan Lingkungan Kerja Terhadap Kinerja Karyawan, Dengan Kepuasan Kerja Sebagai Variabel Mediasi pada PT BNI Lifeinsurance. Jurnal

Pendidikan Ekonomi dan Bisnis (JPEB), 5(1), 73-89.

Harjianto, P. H. (2019). Pengaruh Pengembangan Karier Terhadap Kepuasan Kerja Karyawan Pada PT. Daoben Communication-Kota

Tangerang (Studi Kasus Pada Area Dua Wilayah Ciputat Pamulang Dan Serpong). JENIUS (Jurnal Ilmiah Manajemen Sumber Daya Manusia), 2(2), 299-314.

Hasibuan, M. S. (2013). Manajemen Personalia dan Sumber Daya Manusia. Jakarta: Bumi Aksara.

Hasibuan, Malayu SP. (2016). Manajemen Sumber Daya Manusia. Edisi Revisi. Jakarta: PT Bumi Aksara.

Hendriyaldi, H. (2017). Pengaruh Pelatihan dan Motivasi Terhadap Produktivitas Manajer PT. Sucofindo (Persero) Pusat. Jurnal Benefita: Ekonomi Pembangunan, Manajemen 
Bisnis \& Akuntansi, 2(3), 255266.

Hermawati, R., \& Indriyani, S. (2019). Pengaruh Rekrutmen Dan Kompensasi Terhadap Kinerja Karyawan Pada PT. Sinergi Inti Pelangi. JENIUS (Jurnal Ilmiah Manajemen Sumber Daya Manusia), 3(1), 24-41.

Hermawati, Rahmi. (2017). Analisis

Pengaruh Kompetensi dan

Motivasi Terhadap Kinerja

Karyawan PT. Yasulor

Indonesia. EDUKA: Jurnal

Pendidikan, Hukum, Dan Bisnis, 2(1).

Istijanto (2009). Aplikasi Praktis

Riset Pemasaran. Jakarta: PT. Gramedia Pustaka Utama.

Istijanto (2014) Riset Sumber Daya

Manusia. Jakarta: PT.

Gramedia Pustaka.

Julianry, A., Syarief, R., \& Affandi, M. J. (2017). Pengaruh Pelatihan Dan Motivasi terhadap Kinerja Karyawan serta Kinerja Organisasi Kementerian Komunikasi dan Informatika. Jurnal Aplikasi Bisnis dan Manajemen (JABM), 3(2), 236.

Mangkunegara, A. A. P. (2016). Manajemen sumber daya manusia perusahaan. Bandung: PT. Remaja Rosdakarya.

Rachmawati, R. W. (2017). Pengaruh Pelatihan Dan Motivasi Kerja Terhadap Kinerja Karyawan PT. Bank BJB Kantor Cabang Suci Bandung. Jurnal Manajemen dan Pemasaran Jasa, 9(1), 1-16.
Rivai, Veithzal. (2015) Manajemen Sumber Daya Manusia Untuk Perusahaan. Jakarta: Penerbit PT Raja Grafindo Persada.

Robbins, Stephen., dan Mary Coulter (2012), Manajemen. Jakarta: PT. Indeks Kelompok Gramedia.

Rozi, A., \& Puspitasari, A. (2021). Pengaruh Pengembangan Karir Dan Pelatihan Kerja Terhadap Kinerja Pegawai Pada Dinas Perhubungan Kota Serang. JENIUS (Jurnal Ilmiah Manajemen Sumber Daya Manusia), 4(2), 106-119.

Sedarmayanti. (2016). Sumber Daya Manusia dan Produktivitas Kerja. Jakarta: Mandar Maju.

Sinambela, Lijan Poltak (2016). Manajemen Sumber Daya Manusia. Jakarta: PT Bumi Aksara.

Singgih Santoso (2015). Menguasai Statistik Multivariat. Jakarta: PT Elex Media Komputindo.

Sondang, P.Siagian (2015) Manajemen Sumber Daya Manusia. Jakarta: Bumi Aksara.

Sudjana (2014). Metode Statistika, Bandung: Tarsido.

Sugiyono (2017). Metode Penelitian Kuantitatif Kualitatif dan $R$ \& $D$. Bandung : Penerbit CV. Alfabeta.

Suharsimi Arikunto (2014). Prosedur Penelitian Suatu Pendekatan Praktek. Jakarta: Rineka Cipta. Suhartanto (2014). Metode Riset Pemasaran. Bandung: Alfabeta. 